DOI: $10.52362 /$ jmijayakarta.v1i4.565

\title{
PERANCANGAN DAN IMPLEMENTASI SISTEM APLIKASI INVENTORI BARANG DI PT QUICKTEST LABORATORIUM INDONESIA DENGAN METODE PIECES
}

\author{
${ }^{1}$ Ardi Nor Dzariat, ${ }^{2}$ Sugiyono* \\ Teknik Informatika, STIKOM Cipta Karya Intelektual \\ Email :ardizariat@gmail.com,inosoguy007@gmail.com
}

Received: 2021-08-25, Revised: 2021-08-30, Accepted: 2021-09-02

\begin{abstract}
In the process of managing inventory at PT Quicktest Laboratorium Indonesia, it still uses a semi-computer system that is using the excel application. Problems that occur in this process are errors in inputting the number of incoming and outgoing goods, the length of time in determining goods that have run out, submitting requests for goods that require management approval which requires paper forms and a long time and reporting of stock data is constrained. The solution obtained after analyzing the current system is to implement a pieces analysis to design and implement a web-based inventory system that aims to assist the warehouse department in terms of inventory monitoring and stock reporting to be faster and more accurate. To find out the perceived benefits in building the proposed system, researchers use pieces analysis so that the proposed system can provide maximum benefits in overcoming existing problems.
\end{abstract}

Keywords: Inventory, Blackbox, Web, Analyze Pieces

\begin{abstract}
Abstrak
Pada proses pengelolaan persediaan barang pada PT Quicktest Laboratorium Indonesia masih menggunakan sistem yang semi komputer yaitu menggunakan aplikasi excel. Permasalahan yang terjadi dalam proses ini adalah kesalahan dalam input jumlah barang masuk dan keluar, lamanya dalam menentukan barang yang sudah habis, pengajuan permintaan barang yang membutuhkan persetujuan manajemen yang membutuhkan kertas form dan waktu yang lama serta pelaporan data stok menjadi terkendala. Solusi yang didapatkan setelah menganalisa sistem berjalan adalah mengimplementasikan analisa pieces untuk merancang dan mengimplementasikan sistem persediaan barang berbasis web yang bertujuan untuk membantu bagian gudang dalam hal monitoring persediaan barang dan pelaporan stok menjadi lebih cepat dan akurat. Untuk mengetahui manfaat yang dirasakan dalam membangun sistem usulan peneliti menggunakan analisa pieces agar sistem yang diusulkan dapat memberikan manfaat yang maksimal dalam mengatasi masalah yang ada.
\end{abstract}

Kata Kunci: Inventori, Blackbox, Web, Analisa Pieces

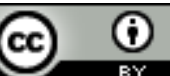

This work is licensed under a Creative Commons Attribution 4.0 International License. http://journal.stmikjayakarta.ac.id/index.php/JMIJayakarta 
DOI: $10.52362 /$ jmijayakarta.v1i4.565

\section{PENDAHULUAN}

Berkembangnya teknologi informasi mengubah manusia dalam menyelesaikan semua pekerjaannya. Dahulu manusia menyimpan semua informasi dan dokumen menggunakan buku yang disimpan dalam lemari dokumen, maka sekarang berubah menggunakan komputer untuk menyimpan data-data suatu perusahaan. Sangat tidak mengherankan apabila instansi-instansi pemerintah maupun perusahaanperusahaan swasta memerlukan peranan komputer, terutama dalam pengolahan data yang masih banyak diantaranya menggunakan cara-cara manual, sehingga efesiensi dan efektivitas pekerjaan yang dibutuhkan tidak sesuai dengan yang diharapkan.

PT Quicktest Laboratorium Indonesia merupakan sebuah perusahaan yang bergerak dibidang pelayanan pemeriksaan kesehatan swab PCR, swab antigen dan rapid test. Pengolahan data pada PT Quicktest Laboratorium Indonesia khususnya pada bagian inventaris barang membutuhkan ketelitian serta keakuratan dalam pencatatan data barang inventaris. Sedangkan pengolahan data secara semi komputerisasi yang sedang berjalan saat ini sudah semakin tidak dapat memenuhi kebutuhan untuk masamasa sekarang karena efisiensi dan efektivitas yang rendah.

Banyaknya data yang harus diolah kemudian disajikan dalam bentuk informasi yang bermanfaat, sehingga manajemen dalam sebuah perusahaan atau instansi tersebut dapat mengambil suatu keputusan dengan cepat dan akurat. Sistem informasi monitoring persediaan barang sangat diperlukan dalam mengelola persediaan barang suatu perusahaan atau instansi agar tidak terjadi kehabisan stok atau penumpukan stok.

Tujuan dalam penelitian ini adalah menganalisa sistem persediaan barang yang sedang berjalan pada PT Quicktest Laboratorium Indonesia, merancang dan menerapkan analisa pieces sistem inventori yang efisien, efektif dan memudahkan user dalam proses mengelola stok barang, permintaan stok barang dan pembelian barang yang dibutuhkan.

\section{TINJAUAN LITERATUR}

\subsection{Kajian Pustaka}

Sistem persediaan barang ini sebelumnya sudah pernah dibuat dan digunakan, namun dengan program aplikasi dan fungsi yang berbeda-beda. Beberapa sistem informasi yang berhubungan dengan persediaan (inventori) yang pernah dibuat:

a. P. Soepomo dalam jurnalnya ditahun 2014, "Perancangan Sistem Informasi Inventori Spare Part Elektronik Berbasis Web php (Studi CV. Human Global Service Yogyakarta)" Dalam penelitiannya membahas tentang inventori atau persediaan bukan merupakan hal yang asing lagi bagi setiap perusahaan. Namun masalah inventori terkadang masih menjadi salah satu kendala untuk mencapai tujuan perusahaan, karena sistem inventori yang tidak terkendali dan tidak adanya pengawasan yang benar serta metode yang dapat dijalankan dengan baik. Hal ini setelah diteliti ternyata disebabkan karena pengelolaan sistem yang masih manual. Dari hal tersebut, maka peneliti merancang dan membuat sistem informasi inventori berbasis web, dimana sistem tersebut dapat diakses secara online. Sehingga untuk mendapatkan informasi laporan dapat diakses dengan mudah dan cepat.

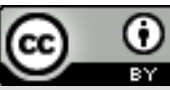

This work is licensed under a Creative Commons Attribution 4.0 International License. http://journal.stmikjayakarta.ac.id/index.php/JMIJayakarta 
DOI: $10.52362 /$ jmijayakarta.v1i4.565

b. Hisbikal Haqqi Muflihin, Harry Dhika dan Santy Handayani ditahun 2020 didalam jurnalnya "Perancangan Sistem Informasi Inventori Pada Toko Rosadah", sistem informasi inventori merupakan sebuah hal keharusan yang harus dimiliki sebuah perusahaan ataupun usaha yang bergerak pada bidang penjualan dan pembelian agar dapat mengolah data transaksi yang berkaitan dengan persedian dapat dilakukan secara efektif dan efisien. Namun pelaksanaan sistem inventori di Toko Rosadah masih menggunakan sistem pengolahan data secara manual, seperti lamanya mencari data penjualan produk, data pembelian produk maupun pencarian stok produk yang sudah habis atau yang akan habis. Untuk dapat mengolah data transaksi yang jumlah cukup banyak diperlukan alat khusus untuk dapat menanganinya oleh sebab itu komputer lah yang menjadi pilihan yang tepat dari berbagai sisi. Dari sisi kecepatan, ketelitian dan keakuratan yang dimilikinya dengan bantuan piranti lunak yang mendukungnya oleh karena itu dibangunlah sebuah sistem informasi inventori dengan menggunakan metode waterfall.

c. Lela Nurlaela, Andy Dharmalau dan Nong Tatu Parida dalam jurnalnya yang berjudul "Rancangan Sistem Informasi Inventori Barang Berbasis Web Studi Kasus Pada CV. Limoplast" diketahui bahwa, belum adanya sistem informasi inventori di CV Limoplast, sehingga bagian marketing kesulitan untuk mendapatkan informasi terkait stok barang yang tersedia saat ada pelanggan yang ingin melakukan pembelian. Dari permasalahan tersebut peneliti membuat sistem aplikasi inventori untuk mempermudah bagian marketing, admin, ataupun pimpinan dalam mendapatkan informasi terkait data persediaan barang. Metodologi penelitian yang digunakan adalah penelitian lapangan, dengan teknik pengumpulan data melalui pengamatan dan wawancara.

d. Mita Rohayati ditahun 2014 dalam jurnalnya yang berjudul "Membangun Sistem Informasi Monitoring Data Inventori Di Vio Hotel Indonesia" menyebutkan bahwa Vio Hotel Indonesia memiliki 3 cabang, sedangkan data inventori antar cabang dikelola masing-masing cabang, sehingga untuk pengecekan inventori di bagian Engineering oleh manajer dilakukan dengan datang langsung ke setiap cabang Vio Hotel Indonesia. Dari permasalahan tersebut, penulis merancang dan membuat sistem informasi monitoring berbasis web yang dionlinekan menggunakan konsep dashboard sebagai model untuk menampilkan hasil monitoring. Sehingga untuk mendapatkan informasi inventori disetiap cabang dapat mudah diakses melalui internet dan data yang dibutuhkan juga cepat dan akurat.

e. Muhamad Tabrani dan Eni Pudjiarti ditahun 2017 dalam jurnalnya yang berjudul "Penerapan Metode Waterfall Pada Sistem Informasi Inventori PT. Pangan Sehat Sejahtera" menyimpulkan permasalahan yang ada di PT. Pangan Sehat Sejahtera adalah pihak kantor pusat tidak dapat mengetahui data inventori masing-masing kantor cabang dengan cepat dan akurat. Dengan memanfaatkan teknologi internet dan sistem aplikasi berbasis web, penulis membuat sistem informasi inventori dengan menerapkan metode waterfall. Dimana aplikasi tersebut dapat terlihat datanya secara online, sehingga kantor pusat dapat melihat data inventori disetiap cabang dengan cepat tanpa harus menunggu

This work is licensed under a Creative Commons Attribution 4.0 International License. http://journal.stmikjayakarta.ac.id/index.php/JMIJayakarta 
DOI: $10.52362 /$ jmijayakarta.v1i4.565

laporan dari kantor cabang setiap hari.

\subsection{Pengertian Metode PIECES}

Analisis PIECES merupakan suatu metode dalam menganalisis dasar untuk memperoleh pokok-pokok pemasalahan yang lebih detail (Ragil, 2010). Analisis PIECES ini berperan penting dalam menentukan analisis dasar sebelum mengembangkan sebuah sistem informasi karena dengan analisis ini maka ditemukan masalah-masalah apa saja yang ada. Metode ini menggunakan enam variabel yaitu:

a. Performance (Kinerja)

Pada vaiabel pertama yaitu kinerja, variabel ini memiliki peran penting untuk menilai apakah suatu prosedur atau proses yang ada masih mungkin bisa ditingkatkan kinerjanya, dan untuk melihat seberapa jauh mana dan handalkah suatu sistem informasi dalam berproses untuk menghasilkan tujuan yang diinginkan.

b. Information (Informasi)

Menilai apakah suatu tugas atau prosedur yang ada saat ini masih dapat ditingkatkan atau diperbaiki sehingga bisa mendapatkan kualitas informasi yang semakin baik. Informasi yang disajikan haruslah benar-benar mempunyai nilai yang berguna.

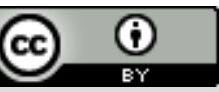

This work is licensed under a Creative Commons Attribution 4.0 International License. http://journal.stmikjayakarta.ac.id/index.php/JMIJayakarta 
DOI: $10.52362 /$ jmijayakarta.v1i4.565

\section{c. Economy (Ekonomi)}

Menilai apakah prosedur yang ada saat ini masih dapat ditingkatkan kegunaannya (manfaatnya) atau diturunkan biaya penyelenggaraannya.

d. Control (Pengendalian)

Menilai apakah tingkat keamanan untuk pengendalian sistem yang ada saat ini masih dapat ditingkatkan sehingga kualitas pengendalian menjadi semakin baik dari sebelumnya, dan kemampuannya untuk mendeteksi kesalahan menjadi semakin baik pula.

e. Efficiency (Efisiensi)

Menilai apakah prosedur pada sistem yang ada saat ini masih dapat ditingkatkan guna tercapainya peningkatan efisiensi dari segi operasi, dan harus lebih unggul dari pada sistem sebelumnya.

f. Service (Layanan)

Menilai apakah prosedur yang ada saat ini masih dapat ditingkatkan kemampuannya guna mencapai peningkatan kualitas layanan kepada pengguna sistem. Buatlah kualitas layanan yang sangat user friendly untuk pengguna (end-user) sehingga pengguna mendapatkan kualitas layanan dari sistem yang baik.

\subsection{Sistem Informasi}

Menurut Yakub (2012:16) mengemukakan bahwa "Sistem informasi (information sistem) merupakan kombinasi teratur dari orang-orang, perangkat keras (hardware), perangkat lunak (software), dan sumber daya data yang mengumpulkan, dan menyebarkan informasi dalam sebuah organisasi". Pengertian menurut Kadir (2014:9), Sistem informasi adalah "sebuah rangkaian prosedur formal dimana data dikelompokkan, diproses menjadi informasi, dan didistribusikan kepada pemakai”.

\subsection{UML}

UML merupakan bahasa visual yang menjadi standar untuk menspesifikasikan, menggambarkan, membangun, dan dokumentasi dari sistem perangkat lunak (Sugiarti, 2013: 34). Dengan kata lain UML adalah sebuah bahasa permodelan untuk memvisualisasikan dan mendokumentasikan suatu hasil analisa dan desain yang memodelkan suatu rancangan sistem secara visual.

\section{METODE PENELITIAN}

\subsection{Tahapan Penelitian}

Penelitian ini menggunakan analisis pieces untuk menentukan rancang bangun sistem informasi monitoring persediaan barang berbasis web yang akan dibuat. Langkah penyelesaian penelitian yang dilakukan adalah:

a. Analisa Sistem

Dalam proses analisa yang dilakukan terdapat dua tahapan yaitu analisa terhadap sistem yang berjalan dan analisa terhadap sistem yang diusulkan. Dalam menganalisis sistem berjalan peneliti menggunakan tahapan analisis pieces yang mana dari tahap analisis ini akan menentukan bentuk sistem yang selanjutnya akan diusulkan dan dibuat (Nawang, Kurniawati, \& Duta, 2017).

b. Pemodelan Sistem

Yaitu pembuatan model dari sistem informasi yang dibuat dengan menggunakan UML.

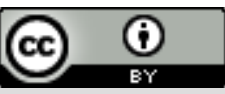

This work is licensed under a Creative Commons Attribution 4.0 International License. http://journal.stmikjayakarta.ac.id/index.php/JMIJayakarta 
DOI: $10.52362 /$ jmijayakarta.v1i4.565

c. Rancangan Dan Implementasi Sistem

Proses rancangan dan implementasi sistem dilakukan untuk membuat aplikasi sistem inventori persediaan barang sesuai dengan kebutuhan.

d. Pengujian Sistem

Pengujian dilakukan agar menghindari kesalahan sistem dan sistem yang dibuat sesuai dengan yang dirancang.

Berdasarkan penelitian yang telah dilakukan sistem pencatatan persediaan barang yang terjadi pada PT Quicktest Laboratorium Indonesia masih manual (menggunakan microsoft excel) dalam mencatat barang yang masuk dan keluar serta melaporkan data stok barang dapat mengakibatkan kesalahan dan kurang efektif sehingga dapat menjadikan kerugian bagi pihak perusahaan jika terjadi kesalahan input ataupun file yang rusak.

\section{HASIL DAN PEMBAHASAN}

\subsection{Analisis Sistem Metode Pieces}

Analisis menggunakan metode pieces ini dapat diuraikan dalam bentuk tabel dibawah ini:

a. Kinerja (Performance)

\begin{tabular}{l} 
Sistem Berjalan \\
\hline Pencatatan data barang masuk, barang keluar \\
dan pembuatan laporan masih menggunakan \\
tulisan tangan sehingga membutuhkan waktu \\
yang cukup lama serta penyimpanan data \\
masih berupa arsip.
\end{tabular}

b. Informasi (Information)

\section{Sistem Usulan}

Data barang masuk, barang keluar, permintaan barang stok room dan permintaan pembelian barang dapat diinput melalui aplikasi berbasis begitu juga untuk laporan dapat dicetak dan ditampilkan melalui aplikasi. Kinerja yang dihasilkan sistem menjadi lebih cepat dan penyimpanan data sudah terintegrasi dalam sebuah database .

\section{Table 1 Analisa Kinerja (Performance)}

Sistem Berjalan
Data stok barang yang masuk, barang keluar,
permintaan barang stok room, permintaan
pembelian barang masih dicatat manual
melalui aplikasi excel sehingga dapat terjadi
human error karena salah input dan akan
mengakibatkan kerugian bagi perusahaan dan
informasi yang akan diberikan tidak valid.

\section{Sistem Usulan}

Data stok diinput melalui sistem sehingga lebih cepat dan update. Serta informasi yang disajikan lebih jelas dan terstruktur.

c. Ekonomi (Economy)

\section{Table 2 Analisa informasi (Information)}

Sistem Berjalan Sistem Usulan

Biaya pengadaan kertas untuk mencetak dan Dalam sistem informasi usulan, penyimpanan

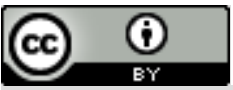

This work is licensed under a Creative Commons Attribution 4.0 International License. http://journal.stmikjayakarta.ac.id/index.php/JMIJayakarta 
DOI: $10.52362 /$ jmijayakarta.v1i4.565

menulis data yang ada dalam gudang cukup mahal dalam jangka waktu yang panjang. data sudah menggunakan database, sehingga penyimpanan data lebih lebih hemat dalam jangka waktu yang panjang.

d. Kontrol (Control)

\section{Table 3 Analisa Ekonomi (Economy)}

\section{Sistem Berjalan}

Keamanan informasi dan data yang ada kurang dikontrol dengan baik karena tidak adanya suatu penyimpanan yang terstruktur seperti database. Penyimpanan data masih berupa file excel yang tersimpan didalam penyimpanan komputer saja.

\section{Sistem Usulan}

Pada sistem baru adanya pembatasan hak akses pengguna dan log history yang memudahkan pengontrolan keamanan sehingga dapat mendeteksi adanya penyalahgunaan akses pada sistem. Dengan adanya sistem baru dapat memudahkan pengguna dalam mengontrol data barang- barang dan informasi yang masuk dan keluar.

e. Efisiensi (Efficiency)

\section{Table 4 Analisa Kontrol (Control)}

\begin{tabular}{l} 
Sistem Berjalan \\
\hline Proses-proses yang dilakukan sistem lama \\
memakan cukup banyak waktu dan biaya \\
sehingga dinilai kurang efisien dan kurang \\
efektif. Dengan adanya keadaan tersebut \\
membuat pengambilan keputusan sedikit lama \\
karena informasi yang didapat juga \\
membutuhkan waktu. Pada sistem yang berjalan \\
kegiatan permintaan barang memerlukan service \\
level agreement yang merepotkan dan lambat \\
dikarenakan harus adanya persetujuan dari level \\
manajemen.
\end{tabular}

\section{Sistem Usulan}

Dengan menggunakan sistem baru diharapkan dapat membuat proses pengolahan data dan informasi lebih cepat dan tepat. Sistem yang baru juga dapat mempermudah pengguna dalam memasukan data, mencari data, dan memperoleh informasi yang dibutuhkan dengan cepat dan akurat dikarenakan sistem dikembangkan berbasis web sehingga lebih fleksibel.

\section{Table 5 Analisa Efisiensi (Efficiency)}

f. Layanan (Service)

\section{Sistem Berjalan}

Pengguna kesulitan dalam melakukan aktifitas pada bagian gudang terutama dalam aktivitas permintaan barang stokroom apabila ingin meminta barang hanya satu item saja harus mengisi formulir permintaan dan harus sudah di tanda tangan persetujuanoleh section head. Keterlambatan dalam melaporkan data

\section{Sistem Usulan}

Sistem informasi yang diusulkan mengurangi keterlambatan dalam persetujuan permintaan barang dan melaporkan data persediaan kepada pimpinan sehingga dapat meningkatkan pelayanan.

\section{(i)}

This work is licensed under a Creative Commons Attribution 4.0 International License. http://journal.stmikjayakarta.ac.id/index.php/JMIJayakarta 
DOI: $10.52362 /$ jmijayakarta.v1i4.565

persediaan kepada pimpinan.

\section{Table 6 Analisa layanan}

\subsection{Pemodelan Sistem}

Tahap penelitian selanjutnya adalah membuat pemodelan sistem. Untuk pemodelan sistem persediaan barang menggunakan UML (Unified Modeling Language) sebagai gambaran bentuk dari alur sistem yang diusulkan.

a. Use case

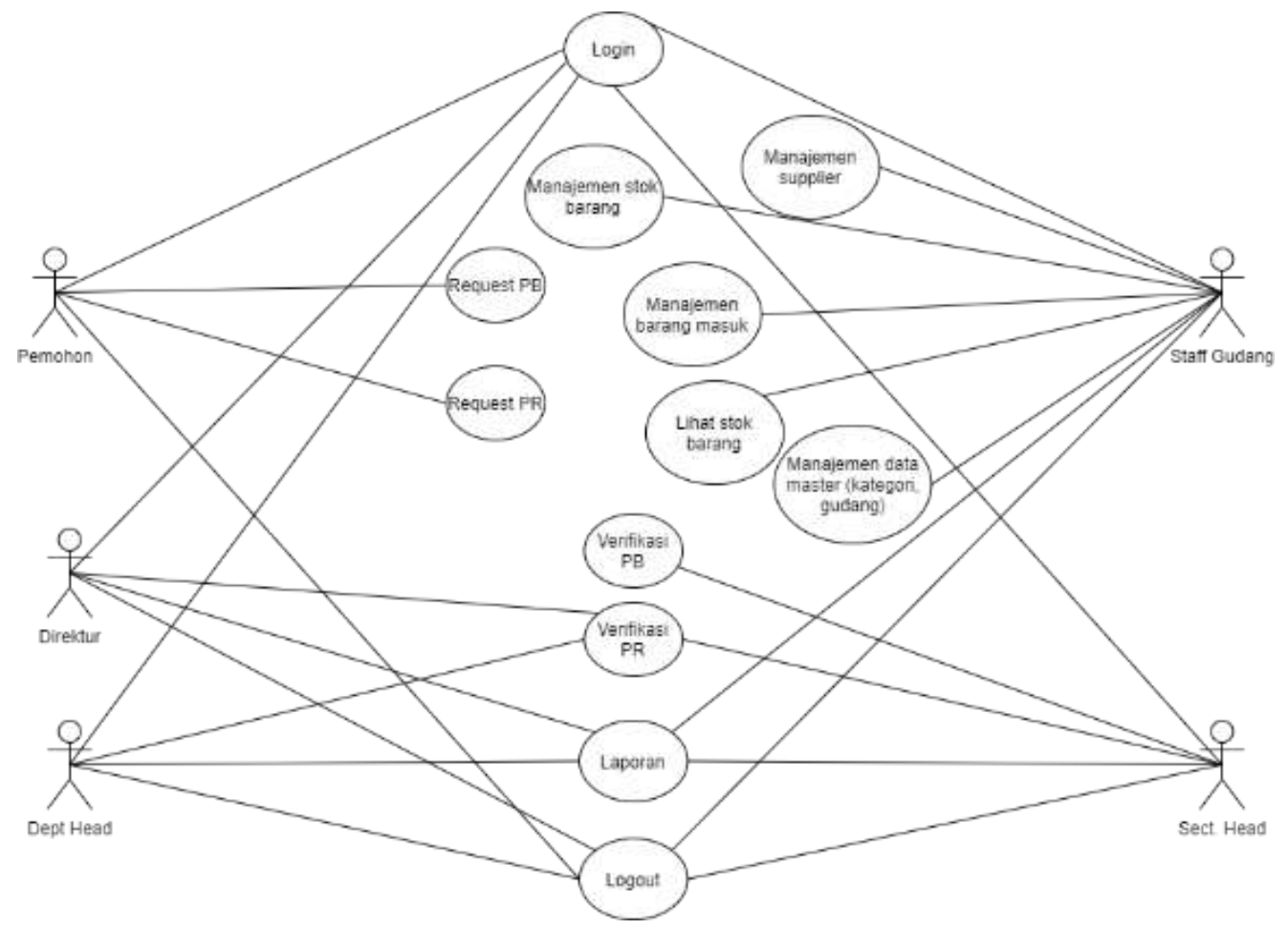

Gambar 1 Use case

(c)

This work is licensed under a Creative Commons Attribution 4.0 International License. http://journal.stmikjayakarta.ac.id/index.php/JMIJayakarta 
DOI: $10.52362 /$ jmijayakarta.v1i4.565

\subsection{Rancangan dan Implementasi Sistem}

Berikut merupakan implementasi dari rancangan yang dibuat untuk sistem persediaan barang berbasis web yang telah dibuat.

a. Login

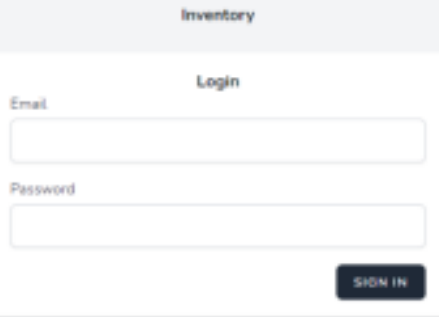

Gambar 2 Login

(9) (1)

This work is licensed under a Creative Commons Attribution 4.0 International License. http://journal.stmikjayakarta.ac.id/index.php/JMIJayakarta 
DOI: $10.52362 /$ jmijayakarta.v1i4.565

b. Produk

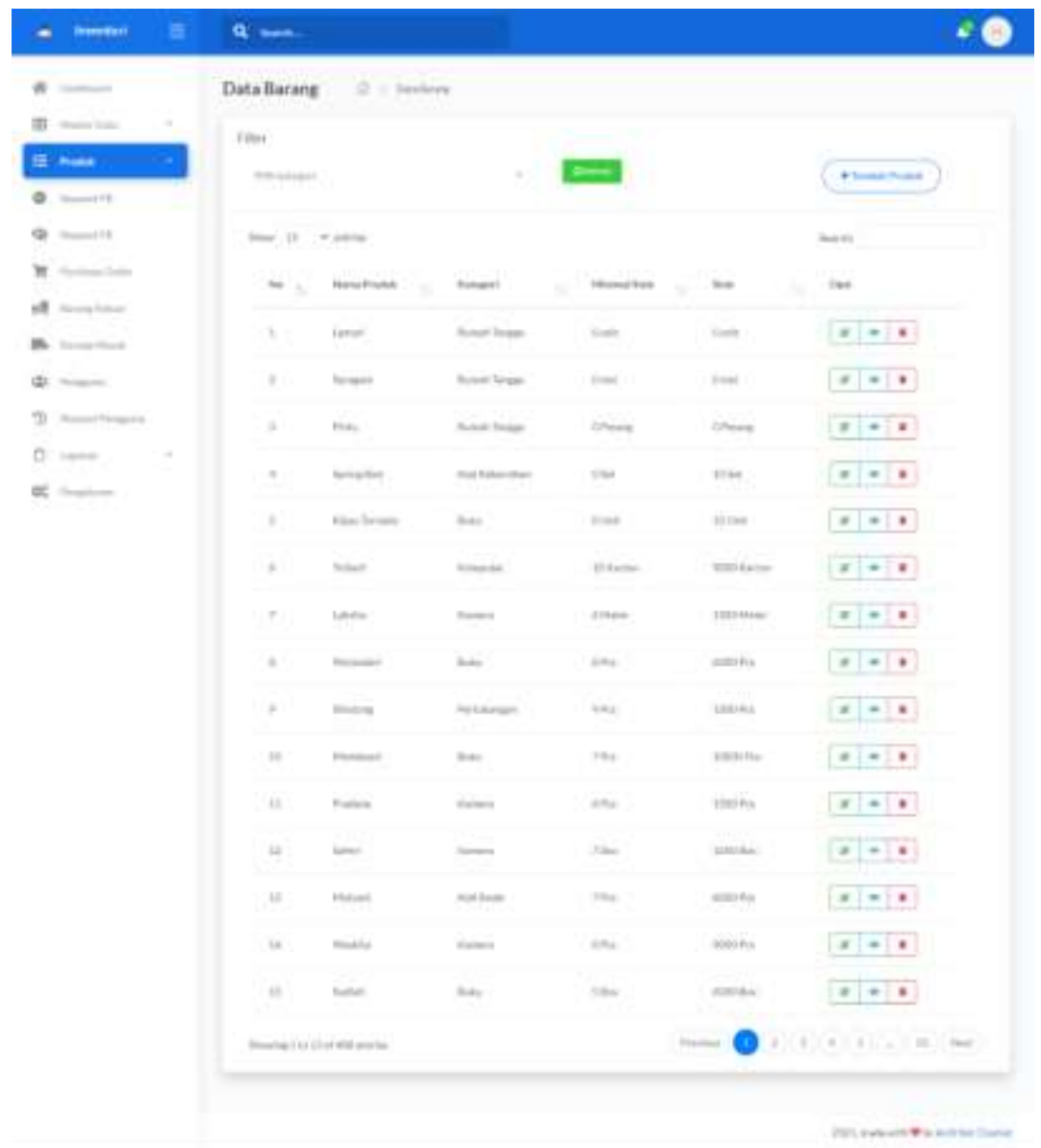

Gambar 3 Data produk

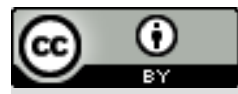

This work is licensed under a Creative Commons Attribution 4.0 International License. http://journal.stmikjayakarta.ac.id/index.php/JMIJayakarta 
DOI: $10.52362 /$ jmijayakarta.v1i4.565

c. Barang masuk

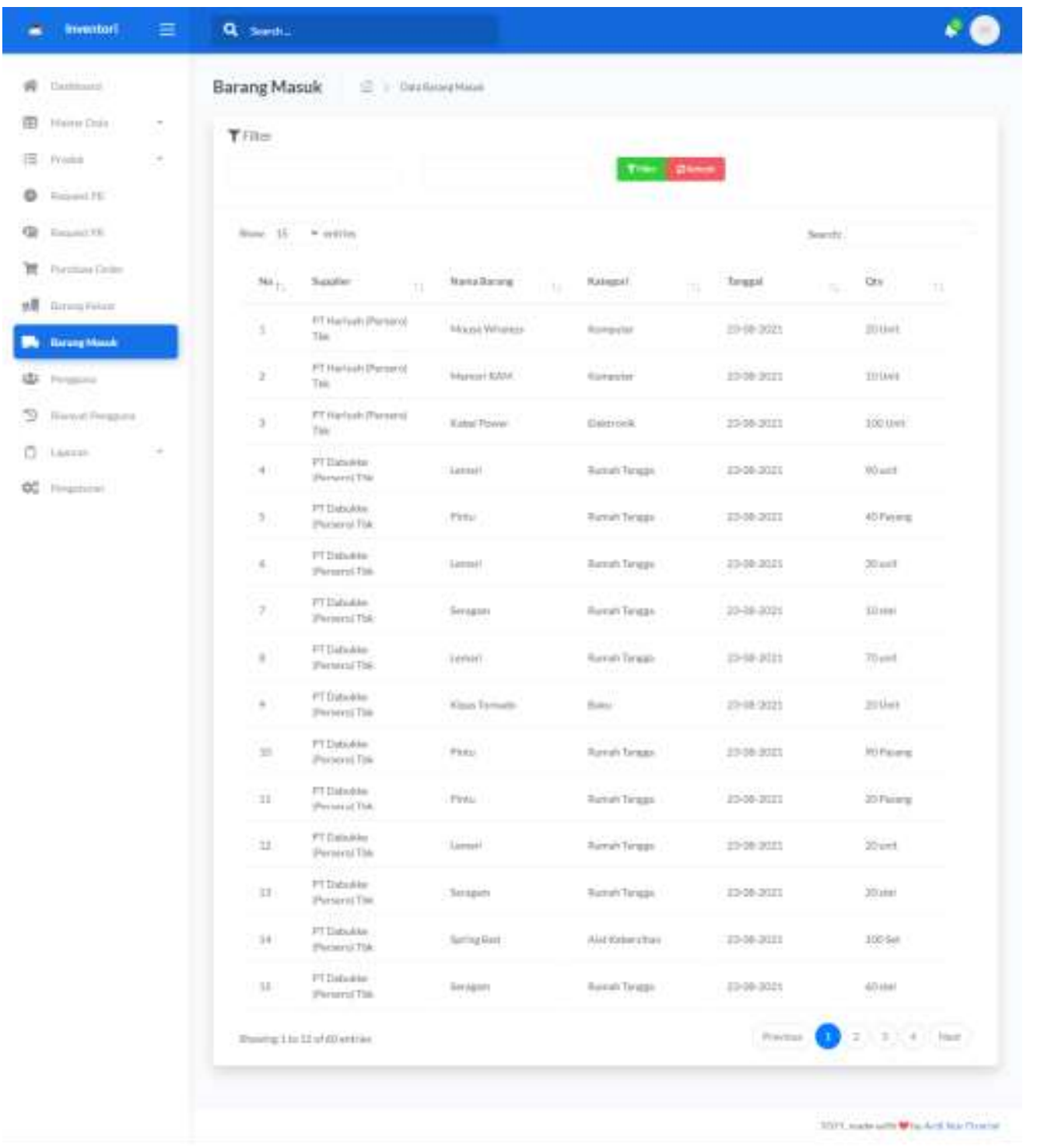

Gambar 4 Data barang masuk

(c) (7)

This work is licensed under a Creative Commons Attribution 4.0 International License. http://journal.stmikjayakarta.ac.id/index.php/JMIJayakarta 
DOI: $10.52362 /$ jmijayakarta.v1i4.565

d. Barang keluar

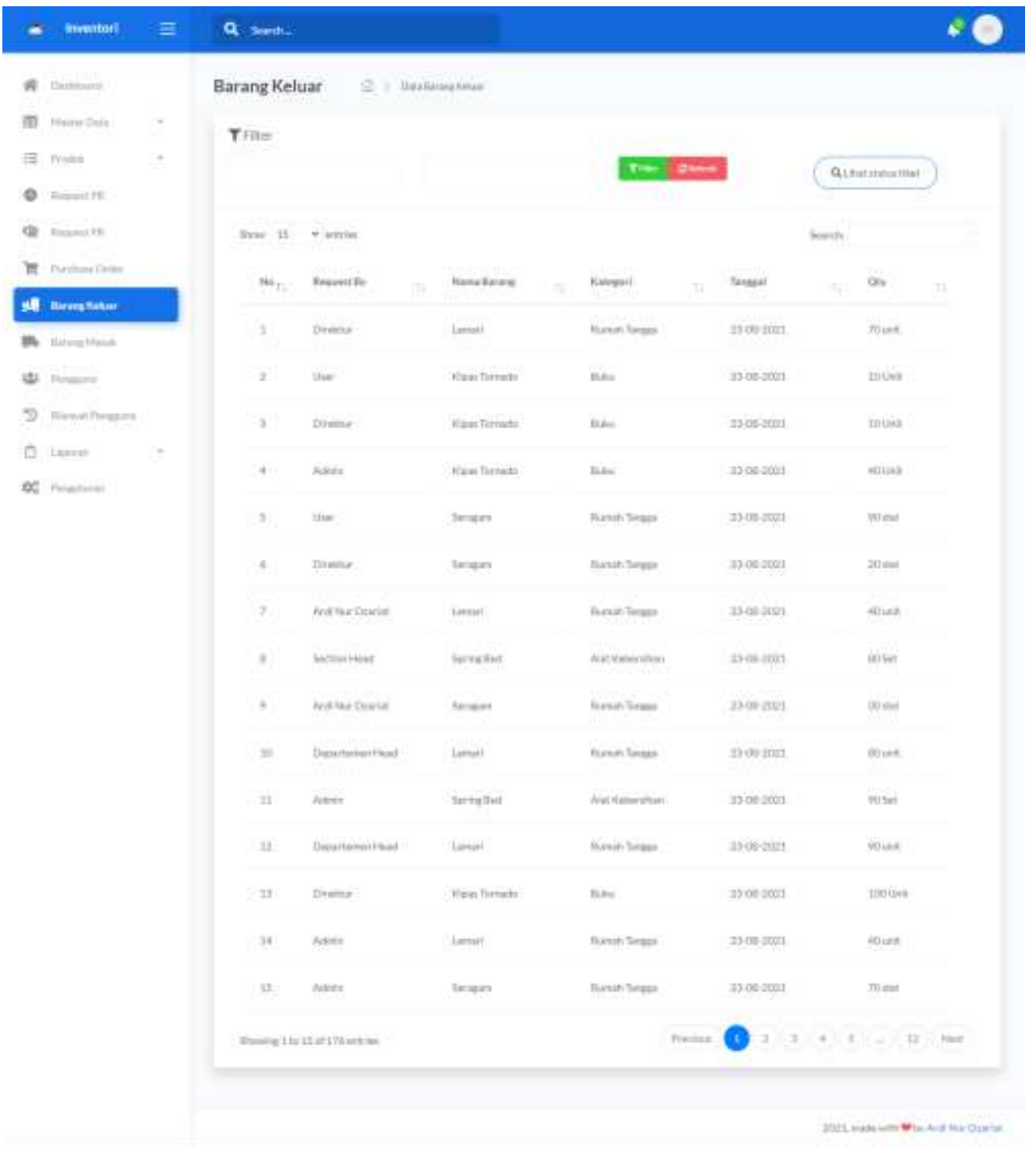

\section{Gambar 5 Data barang keluar}

\subsection{Pengujian Sistem}

Dalam melakukan pengujian sistem informasi yang telah dibuat peneliti menggunakan blackbox testing. Pengujian ini dilakukan untuk menentukan apakah sistem informasi yang diusulkan berjalan sesuai dengan harapan atau tidak.

\begin{tabular}{|c|c|c|c|}
\hline Kasus Uji & Skenario & Hasil yang diharapkan & Hasil \\
\hline Login. & $\begin{array}{l}\text { User melakukan login } \\
\text { dengan data yang benar. }\end{array}$ & $\begin{array}{l}\text { Sistem menampilkan } \\
\text { berhasil login dan }\end{array}$ & \\
\hline
\end{tabular}

\section{(c) (i)}

This work is licensed under a Creative Commons Attribution 4.0 International License. http://journal.stmikjayakarta.ac.id/index.php/JMIJayakarta 
DOI: $10.52362 /$ jmijayakarta.v1i4.565

\begin{tabular}{|c|c|c|c|}
\hline & & halaman dashboard. & \\
\hline Tambah produk & $\begin{array}{l}\text { User menginput data produk } \\
\text { yang baru dengan mengisi } \\
\text { form yang tersedia. }\end{array}$ & $\begin{array}{l}\text { Sistem menampilkan hasil data produk } \\
\text { yang telah diinput ditabel data list } \\
\text { produk. }\end{array}$ & Sesuai \\
\hline $\begin{array}{l}\text { Tambah } \\
\text { permintaan } \\
\text { barang stok } \\
\text { room (PB) }\end{array}$ & $\begin{array}{l}\text { User menginput data } \\
\text { permintaan barang dengan } \\
\text { mengisi form yang tersedia. }\end{array}$ & $\begin{array}{l}\text { Sistem menampilkan hasil data } \\
\text { permintaan barang yang telah diinput } \\
\text { ditabel data list permintaan barang. }\end{array}$ & Sesuai \\
\hline $\begin{array}{l}\text { Tambah } \\
\text { permintaan } \\
\text { pembelian } \\
\text { barang (PR). }\end{array}$ & $\begin{array}{l}\text { User menginput data } \\
\text { permintaan pembelian } \\
\text { barang dengan mengisi form } \\
\text { yang tersedia. }\end{array}$ & $\begin{array}{l}\text { Sistem menampilkan hasil data } \\
\text { permintaan pembelian barang yang } \\
\text { telah diinput ditabel data list } \\
\text { permintaan pembelian barang (PR). }\end{array}$ & Sesuai \\
\hline $\begin{array}{l}\text { Download } \\
\text { laporan barang } \\
\text { masuk. }\end{array}$ & $\begin{array}{l}\text { User pilih barang masuk dan } \\
\text { memilih tanggal ekspor data } \\
\text { berdasarkan tanggal yang } \\
\text { dipilih. }\end{array}$ & $\begin{array}{l}\text { Sistem menampilkan hasil data } \\
\text { laporan barang masuk sesuai tanggal } \\
\text { yang telah dipilih berbentuk pdf. }\end{array}$ & Sesuai \\
\hline $\begin{array}{l}\text { Download } \\
\text { laporan barang } \\
\text { keluar. }\end{array}$ & $\begin{array}{l}\text { User pilih barang keluar dan } \\
\text { memilih tanggal ekspor data } \\
\text { berdasarkan tanggal yang } \\
\text { dipilih. }\end{array}$ & $\begin{array}{l}\text { Sistem menampilkan hasil data } \\
\text { laporan barang keluar sesuai tanggal } \\
\text { yang telah dipilih berbentuk pdf. }\end{array}$ & Sesuai \\
\hline $\begin{array}{l}\text { Download stok } \\
\text { produk. }\end{array}$ & $\begin{array}{l}\text { User menekan tombol } \\
\text { ekspor. }\end{array}$ & $\begin{array}{l}\text { Sistem menampilkan hasil data } \\
\text { laporan barang dengan detail } \\
\text { yang tersedia berbentuk pdf. }\end{array}$ & Sesuai \\
\hline
\end{tabular}

Table 7 Pengujian sistem

\section{KESIMPULAN}

Setelah melakukan suatu analisa terhadap sistem inventori pada PT Quicktest Laboratorium Indonesia maka penulis dapat mengambil kesimpulan sebagai berikut:

a. Sistem persediaan barang yang sedang berjalan pada PT Quicktest Laboratorium Indonesia masih menggunakan sistem manual, yaitu setiap barang yang masuk dan barang yang keluar datanya dimasukan ke dalam aplikasi excel. Hal ini sangat rentan terjadinya kesalahan dan kehilangan data. Dan permintaan barang masih menggunakan form dari kertas yang telah dibuat bagian gudang.

b. Dengan mengamati sistem yang sedang berjalan, kemudian merumuskan masalah yang dihadapi lalu dirancanglah sebuah sistem inventori berbasis web dengan menggunakan bahasa pemrograman PHP dan database MySql diharapkan dapat mempermudah bagian gudang dalam mengelola stok barang.

\section{REFERENSI}

[1] Abdul Kadir. 2014. Pengenalan Sistem Informasi Edisi Revisi. Andi.Yogyakarta

[2] A. R. Anggraini and J. Oliver, "Rancangan Sistem Informasi Inventory Barang Berbasis Web Studi Kasus Pada Cv. Limoplast,” J. Chem. Inf. Model., vol. 53, no. 9, pp. 1689-1699, 2019.

[3] H. H. Muflihin, H. Dhika, and S. Handayani, "Perancangan Sistem Informasi Inventory Pada

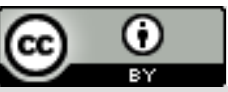

This work is licensed under a Creative Commons Attribution 4.0 International License. http://journal.stmikjayakarta.ac.id/index.php/JMIJayakarta 
DOI: $10.52362 /$ jmijayakarta.v1i4.565

Toko Rosadah,” Bianglala Inform., vol. 8, no. 2, pp. 91-99, 2020, doi: 10.31294/bi.v8i2.8712.

[4] M. Rohayati, "Membangun Sistem Informasi Monitoring Data Inventory Di Vio Hotel Indonesia," J. Ilm. Komput. dan Inform., vol. 1, no. 1, pp. 1-8, 2014.

[5] M. Tabrani, "Penerapan Metode Waterfall Pada Sistem Informasi Inventori Pt. Pangan Sehat Sejahtera," J. Inkofar, vol. 1, no. 2, pp. 30-40, 2018, doi: 10.46846/jurnalinkofar.v1i2.12.

[6] Nawang, M., Kurniawati, L., \& Duta, D. (2017). Rancang Bangun Sistem Informasi Pengolahan Data Persediaan Barang Berbasis Dekstop dengan Model Waterfall. PILAR, 13(2), 233-238.

[7] P. Soepomo, "Perancangan Sistem Informasi Inventory Spare Part Elektronik Berbasis Web Php (Studi CV. Human Global Service YOGYAKARTA)," JSTIE (Jurnal Sarj. Tek. Inform., vol. 2, no. 2, pp. 256-265, 2014, doi: 10.12928/jstie.v2i2.2847

[8] Sugiarti, Yuni, 2013, Analisis dan Perancangan UML (Unified Modeling Language) Generated VB.6, Yogyakarta, Graha Ilmu.

[9] Ragil, Wukil. 2010:17. “Analisis menggunakan Metode Pieces”. Jakarta.

[10] Yakub, 2012, Pengantar Sistem Informasi, Graha Ilmu, Yogyakarta. 